University of South Florida

DIGITAL COMMONS

Digital Commons @ University of

@ UNIVERSITY OF SOUTH FLORIDA

South Florida

4-15-1994

\title{
Interpretation of the Coastal Zone Color Scanner Signature of the Orinoco River Plume
}

Herschel T. Hochman

University of South Florida

Frank E. Muller-Karger

University of South Florida, carib@usf.edu

John J. Walsh

University of South Florida, jwalsh@usf.edu

Follow this and additional works at: https://digitalcommons.usf.edu/msc_facpub

Part of the Marine Biology Commons

\section{Scholar Commons Citation}

Hochman, Herschel T.; Muller-Karger, Frank E.; and Walsh, John J., "Interpretation of the Coastal Zone Color Scanner Signature of the Orinoco River Plume" (1994). Marine Science Faculty Publications. 65. https://digitalcommons.usf.edu/msc_facpub/65

This Article is brought to you for free and open access by the College of Marine Science at Digital Commons @ University of South Florida. It has been accepted for inclusion in Marine Science Faculty Publications by an authorized administrator of Digital Commons @ University of South Florida. For more information, please contact digitalcommons@usf.edu. 


\title{
Interpretation of the coastal zone color scanner signature of the Orinoco River plume
}

\author{
Herschel T. Hochman, F. E. Müller-Karger, and John J. Walsh \\ Department of Marine Science, University of South Florida, St. Petersburg
}

\begin{abstract}
The Caribbean Sea is an area that traditionally has been considered oligotrophic, even though the Orinoco River contributes large quantities of fresh water, nutrients, and other dissolved materials to this region during the wet boreal (fall) season. Little is known about the impact of this seasonal river plume, which extends from Venezuela to Puerto Rico shortly after maximum discharge. Here we present results from a study of the bio-optical characteristics of the Orinoco River plume during the rainy season. The objective was to determine whether the coastal zone color scanner (CZCS) and the follow-on sea-viewing wide-field-of-view sensor (SeaWiFS) satellite instrument can be used to assess the concentrations of substances in large river plumes. Recent in situ shipboard measurements were compared to values from representative historical CZCS images using established bio-optical models. Our goal was to deconvolve the signatures of colored dissolved organic carbon and phytoplankton pigments within satellite images of the Orinoco River plume. We conclude that the models may be used for case II waters and that as much as $50 \%$ of the remotely sensed chlorophyll biomass within the plume is an artifact due to the presence of dissolved organic carbon. Dissolved organic carbon originates from a number of sources, including decay of dead organisms, humic materials from the soil, and gelbstoff.
\end{abstract}

\section{Introduction}

Our analysis of river-borne dissolved and particulate matter considers a region bound by $7^{\circ}$ to $21^{\circ} \mathrm{N}$ and $56^{\circ}$ to $76^{\circ} \mathrm{W}$ (Figure 1). Because the influence of the Amazon River on this region is limited during the rainy season of AugustNovember [Müller-Karger et al., 1988], the Orinoco River remains the most important freshwater source of colored dissolved organic carbon (CDOC) affecting "apparent" pigment distributions sampled by the coastal zone color scanner (CZCS) [Müller-Karger et al., 1989]. Nutrient addition by this river certainly leads to growth of diatom-dominated phytoplankton communities, particularly near the continental margin [Bidigare et al., 1993], but we are concerned about possible CDOC contamination of remotely sensed color signals attributed solely to algal biomass [Walsh et al., 1992].

During the wet season (August-November), for example, sufficient nutrients are added by riverine and shelf break upwelling sources off South America to sustain growth, with resultant senescence and decay of an unknown amount of phytoplankton within the Caribbean basin [Walsh et al., 1981]. CDOC is also added by river and shelf sources, how ever, so recent satellite-based estimates of coastal primary production [Platt et al., 1991] may be overestimated as a consequence of such CDOC stocks. The combined color signals of phytoplankton and CDOC are seen by CZCS imagery as a plume of apparent pigment extending up to 1200 $\mathrm{km}$ northwestward from the Venezuelan coast (Plate 1). Since these images are 1 month apart, some variability

Copyright 1994 by the American Geophysical Union.

Paper number 93JC02152. 0148-0227/94/93JC-02152\$05.00 would be expected. The color signal may be significantly affected by CDOC at lower pigment concentrations.

Shipboard samples of CDOC and pigments were collected in the Orinoco River plume during September 1988 by Blough et al. [1993] and Bidigare et al. [1993]. Measurement techniques consisted of high-performance liquid chromatography (HPLC) for pigments [Bidigare et al., 1993] and high-temperature catalytic combustion for DOC [Blough et al., 1993]. Two CZCS composite images are shown in Plate 1 for the weeks of September 2-7, 1979, and October 3-9, 1979. Our interest is to compare fall plume conditions of satellite-sensed pigment with shipboard estimates of CDOC and chlorophyll. Although the satellite imagery and in situ data were collected in different years, repetitive color signatures of the Orinoco River occur each year in the southeastern Caribbean Sea [Müller-Karger et al., 1989]. It is assumed that the 1988 in situ data are also comparable to those of previous years.

We examined these CZCS images for several conditions. Atmospheric effects were first analyzed to determine whether aerosol corrections in addition to those effected by default parameters would have to be made to the CZCS data. Once this question was answered, the effect of backscatter was examined using established relationships [Gordon and Morel, 1983] to obtain corrected backscatter coefficients for the Orinoco River plume. Introducing these corrected values in a bio-optical model developed by Gordon et al. [1988], CDOC was next calculated from in situ pigment data [Bidigare et al., 1993] at three stations. To account for variation in CDOC, when comparing in situ and satellite data, a final analysis was made of the specific absorption coefficients associated with CDOC. The modeled CDOC values were validated using Blough et al.'s [1993] in situ data. 


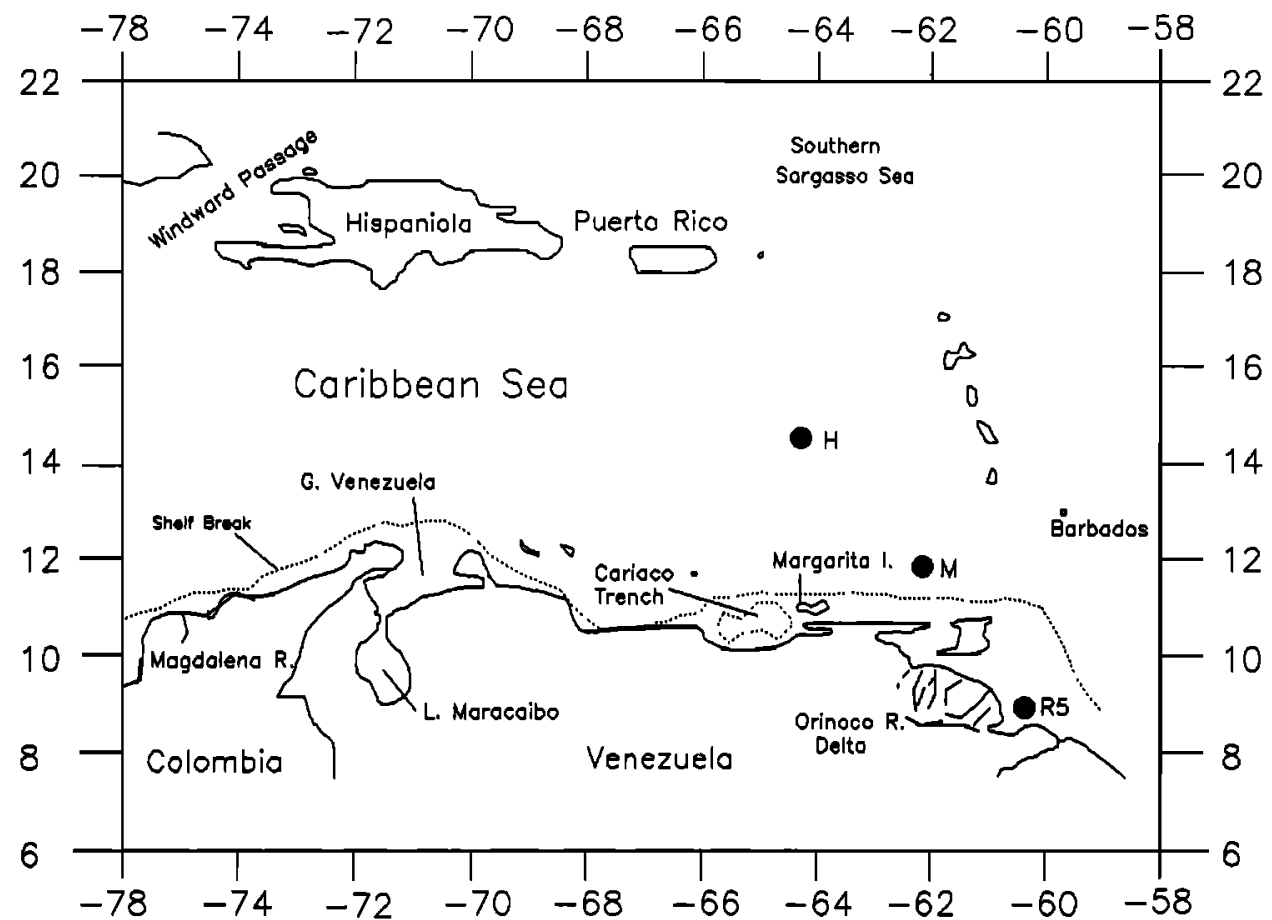

Figure 1. The southeastern Caribbean Sea with locations of stations R5, M, and H [after Bidigare et al., 1993; Blough et al., 1993].

\section{Methods}

\subsection{Atmospheric Radiance}

The contribution of the aerosol path radiance $L_{a}$ to the total radiance $L_{t}$ measured by the CZCS at each wavelength $\lambda$ is defined by Gordon et al. [1983] as

$$
L_{f}(\lambda)=L_{r}(\lambda)+L_{a}(\lambda)+t(\lambda) L_{w}(\lambda)
$$

where $L_{r}$ is the path radiance caused by Rayleigh scattering, $L_{w}$ is water-leaving radiance, and $t$ is the diffuse transmittance of the atmosphere. Equation (1) decouples the ocean's and atmosphere's radiances, where $t(\lambda) L_{w}(\lambda)$ contains all the information on the dissolved and suspended materials in the water.

The usual atmospheric correction procedure employs band $4(670 \mathrm{~nm})$ of the CZCS for calculating $L_{a}$, since it is assumed that water absorbs all light at this wavelength in waters with negligible pigment concentration (i.e., $L_{w}(670)$ $=0)$. Since sediments within nearshore environments may scatter at this wavelength, however, it is possible that $L_{a}(\lambda)$ is overestimated in this region of the Orinoco River plume. Without further correction, $L_{w}$ at 443,520 , and $550 \mathrm{~nm}$ would thus be underestimated. To address this problem, separate regions within and outside the plume (Plate 1) were analyzed for covarying effects in the $670-\mathrm{nm}$ band and the apparent pigment distribution.

Another factor that might affect reflectance at $L_{a}(670)$ is backscatter due to coccolithophores in surface waters. Their concentration was recently thought to be insignificant within the river plume [Betzer et al., 1977]. However, Bidigare et al. [1993] do indicate the presence of coccolithophores (i.e., prymnesiophytes) at stations $M$ and $H$ (Figure 1), but their abundance or depth may not be sufficient to affect the color of water. We ignored backscattering properties of heterotro- phic bacteria [Ulloa et al., 1992]; their abundance within the plume remains unquantified.

\subsection{Water-Leaving Radiance}

The water-leaving radiance $L_{w}(\lambda)$ derived from the CZCS depends on the concentrations of colored constituents, including CDOC, chlorophyll, and phaeopigments. For offshore case I [Morel and Prieur, 1977] waters and mixtures of case I and nearshore case II waters, CDOC has generally been ignored or assumed to covary with the concentration of algal pigments $\langle C\rangle$. Prior algorithms empirically related the ratio of $L_{w}(\lambda)$ at different wavelengths to $\langle C\rangle$ in the following manner [Gordon and Clark, 1981; Gordon et al., 1983]:

$$
\log \langle C(i j)\rangle=\log A(i j)+B(i j) \log R(i j)
$$

where $(C(i j))$ is the optically weighted pigment concentration within the first attenuation length $K_{T}^{-1}$. The $A(i j)$ and $B(i j)$ terms are regression coefficients, while $R(i j)=L_{w}(i) /$ $L_{w}(j)$, in which $(i, j)=(443,550 \mathrm{~nm})$ for $\langle C\rangle<1.5 \mathrm{mg}$ $\mathrm{m}^{-3}$ and $(i, j)=(520,550 \mathrm{~nm})$ for $\langle C\rangle>1.5 \mathrm{mg} \mathrm{m}^{-3}$.

The normalized water-leaving radiance is modeled by Gordon et al. [1988] as

$$
\left[L_{w}\right]_{N}=\left[(1-\rho)(1-\bar{\rho}) F_{0} R /\left(m^{2} Q(1-R r)\right)\right]
$$

where $\left[L_{w}\right]_{N}$ is normalized to remove atmospheric variability and changes in solar zenith angle [Gordon and Clark, 1981]; $\rho$ is the Fresnel reflectance of the sea surface for normal incidence $(0.021) ; \bar{\rho}$ is the Fresnel reflectance albedo (0.043); and $F_{0}$ is the wavelength-dependent extraterrestrial solar irradiance [Gordon et al., 1983]. Here $R$ is the irradiance reflectance just beneath the sea surface, defined as

$$
R=E_{u} / E_{d}
$$



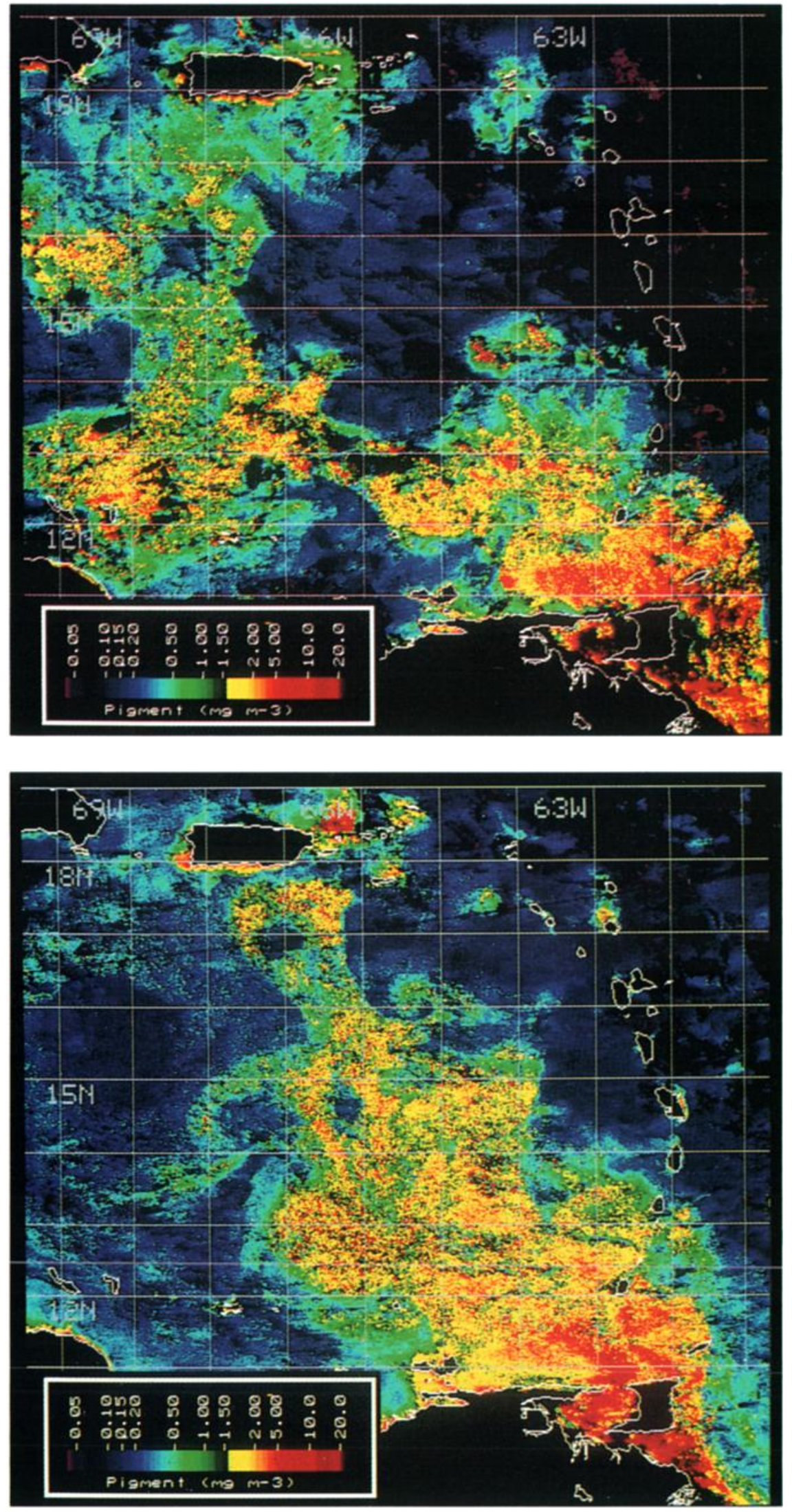

Plate 1. CZCS weekly composites of the southeastern Caribbean Sea on (top) September 2-7, 1979, and (bottom) October 3-9, 1979. The Orinoco River plume covers the eastern Caribbean and appears to flow northwestward past Puerto Rico. Warm colors (yellow, orange, red) represent a combination of high pigment and CDOC concentrations. Blue represents clear water. 
where $E_{u}$ and $E_{d}$ are the upwelling irradiance just below the surface of the water and the downwelling irradiance just above the surface, respectively [Smith and Baker, 1978a, b]. The index of refraction of water $m$ is taken to be 1.3 , while $Q$ (ratio of the upwelling radiance to the upwelling irradiance toward the zenith) is equal to $\pi$, and $r$ is the water-air reflectance for totally diffuse irradiance. In the last term of (3), $(1-R r), r$ is about 0.48 and accounts for the effect of internal reflectance of the upwelling radiance field by the sea surface [Gordon et al., 1988]. The whole term is approximately equal to 1 .

Now, the spectral reflectance $R(\lambda)$ is dependent upon both the absorption $\alpha$ and the backscattering $b_{b}$ of light. A relationship between the inherent absorption and scattering properties of water and $R / Q$ is described [Gordon et al., 1988] by

$$
\left[L_{w}\right]_{N} \approx R / Q=0.110 b_{b} / K_{T}
$$

where $b_{b}$ is defined as the total backscattering, and $K_{T}$ is the total diffuse attenuation of water and its dissolved and particulate constituents.

While phytoplankton pigments and CDOC strongly influence $\alpha$, which is related to $K_{T}$ by the average value of the subsurface solar zenith angle [Gordon and Morel, 1983; Gordon et al., 1988], it has been commonly assumed that they have little effect on $b_{b}$. However, it is seen [Morel and Prieur, 1977; Gordon et al., 1988] that

$$
b_{b}=\left(b_{b}\right)_{p}+\left(b_{b}\right)_{w}
$$

where $\left(b_{b}\right)_{p}$ is backscattering due to phytoplankton and their associated detrital material, and $\left(b_{b}\right)_{w}$ is backscattering of pure seawater, that is, half of its molecular scattering coefficient [Morel, 1974]. For case I waters with low pigment concentrations, backscattering due to detrital material dominates [Morel and Prieur, 1977], whereas absorption due to light-absorbing components within the detritus is probably not significant. One could expand (6) to include backscattering contributed by heterotrophic bacteria, which may be $\approx 3 \%$ of the total backscattering in the oligotrophic Sargasso Sea and $7 \%$ in the eutrophic Georges Bank [Ulloa et al., 1992].

At low pigment concentrations, most of the particle backscattering presumably results from detrital material. Generally, as the phytoplankton abundance increases, the ratio of viable phytoplankton to detrital material also increases such that the phytoplankton then have a relatively greater effect on the optical properties. Therefore the relationship between $\langle C\rangle$ and $L_{w}\left(\lambda_{2}\right) / L_{w}\left(\lambda_{1}\right)$ via (2)-(5) is complex and nonlinear [Gordon et al., 1983, 1988].

\subsection{Bio-optical Model}

The total $K_{T}(\lambda)$ is defined [Smith and Baker, 1978a, b] as

$$
K_{T}(\lambda)=K_{W}(\lambda)+K_{C}(\lambda)+K_{y s}(\lambda)
$$

in which

$$
\begin{aligned}
& K_{C}(\lambda)=k_{c}(\lambda) \times C_{K} \times\left\{\operatorname { e x p } \left[-k_{c}^{\prime 2}(\lambda)\right.\right. \\
&\left.\times\left(\log _{10}\left(C_{K^{\prime}} / C_{0}\right)\right]^{2}\right\}+0.001 C_{K}^{2}
\end{aligned}
$$

is the term due to phytoplankton pigments, and

$$
K_{y s}(\lambda)=Z_{0}\left[\alpha_{y s}(375)-0.06\right] \times \exp [-0.014(\lambda-375)]
$$

is the term due to CDOC. $K_{W}$ is the diffuse attenuation coefficient for clear ocean water (reciprocal meters).

In (8) and (9), $k_{c}$ is a specific attenuation coefficient $\left(\mathrm{m}^{-1}\right.$ (mg pigment $\left.\mathrm{m}^{-3}\right)^{-1}$ ) for pigments, $k_{c}^{\prime}$ is a spectral-fit parameter [Baker and Smith, 1982], $C_{0}$ is the surface concentration of chlorophyll (chl) $a$ plus phaeopigments (milligrams pigment per cubic meter), and $C_{K}$ is the average pigment concentration (milligrams per cubic meter) over a depth of 1 attenuation length. Similarly, $\alpha_{y s}$ is the absorption coefficient for yellow substances, or CDOC (reciprocal meters) and $Z_{0} \approx 1 / \cos \theta_{0 w}$ is the downwelling distribution function, which is dependent on the subsurface solar zenith angle and is set to 1.1 .

We also define

$$
\alpha_{y s}(375)=\left[k_{d}\left(\lambda_{0}\right) \times D\right]
$$

where $D$ is the CDOC concentration in milligrams per liter, and $\alpha_{y s}(375)$ is defined in (9) as $0.06 \mathrm{~m}^{-1}$ for the "background" CDOC concentration found in oligotrophic waters such as the Sargasso Sea [Gordon et al., 1988], that is, for $K_{y s}(\lambda)=0$. In $(10), k_{d}\left(\lambda_{0}\right)$ is the specific attenuation coefficient for CDOC, that is, $\left.0.565 \mathrm{~m}^{-1}(\mathrm{mg} \mathrm{DOC} \mathrm{L})^{-1}\right)^{-1}$ at $375 \mathrm{~nm}$ for case I waters [Baker and Smith, 1982]. Using this value in the water-leaving radiance model [Gordon et al., 1988 ] yields a background CDOC concentration of $0.106 \mathrm{mg}$ $\mathrm{L}^{-1}$, for example.

Figure 2 shows the spectral contribution [Baker and Smith, 1982] of each constituent to the total diffuse attenuation coefficient $K_{T}$ at a nominal CDOC concentration of 0.5 $\mathrm{mg} \mathrm{L}^{-1}$, a chlorophyll $a$ plus phaeopigment concentration of $1 \mathrm{mg} \mathrm{m}^{-3}$, and pure water. Since CDOC has a low scattering to absorption ratio, we may increase CDOC above $0.106 \mathrm{mg}$ $\mathrm{L}^{-1}$ and still use the models of Gordon et al. [1988]. With (7)-(10) we can also explore the consequences of inputs of allochthonous (terrigenous) or autochthonous (marine) CDOC, since each of these may have characteristic spectral slopes and specific absorption coefficients.

\subsection{Backscattering Model}

We have not yet, however, related the particulate backscattering coefficient $\left(b_{b}\right)_{p}$ of (6) to the phytoplankton pigment concentration. We follow Gordon and Morel [1983] in assuming that $\left(b_{b}\right)_{p}$ varies with wavelength and pigment concentration $C$ by the empirical relationship

$$
\left(b_{b}\right)_{p}=A(\lambda) C^{B(\lambda)}
$$

where $A(\lambda)$ (reciprocal meters) and $B(\lambda)$ are again wavelength-dependent constants but different from those in (2). In addition, it is assumed that the Caribbean Sea with its associated plumes can be categorized by the same case I and case II waters denoted by Morel and Prieur [1977].

$A(\lambda)$, for particulate backscattering, can be related to a similar factor for total scattering, $b^{0}$ (reciprocal meters). The total scattering coefficient, $b(\lambda)$ at $550 \mathrm{~nm}$, for example, has been empirically related to the pigment concentration [Gordon and Morel, 1983] by

$$
b(550)=b^{0} C^{0.62}
$$




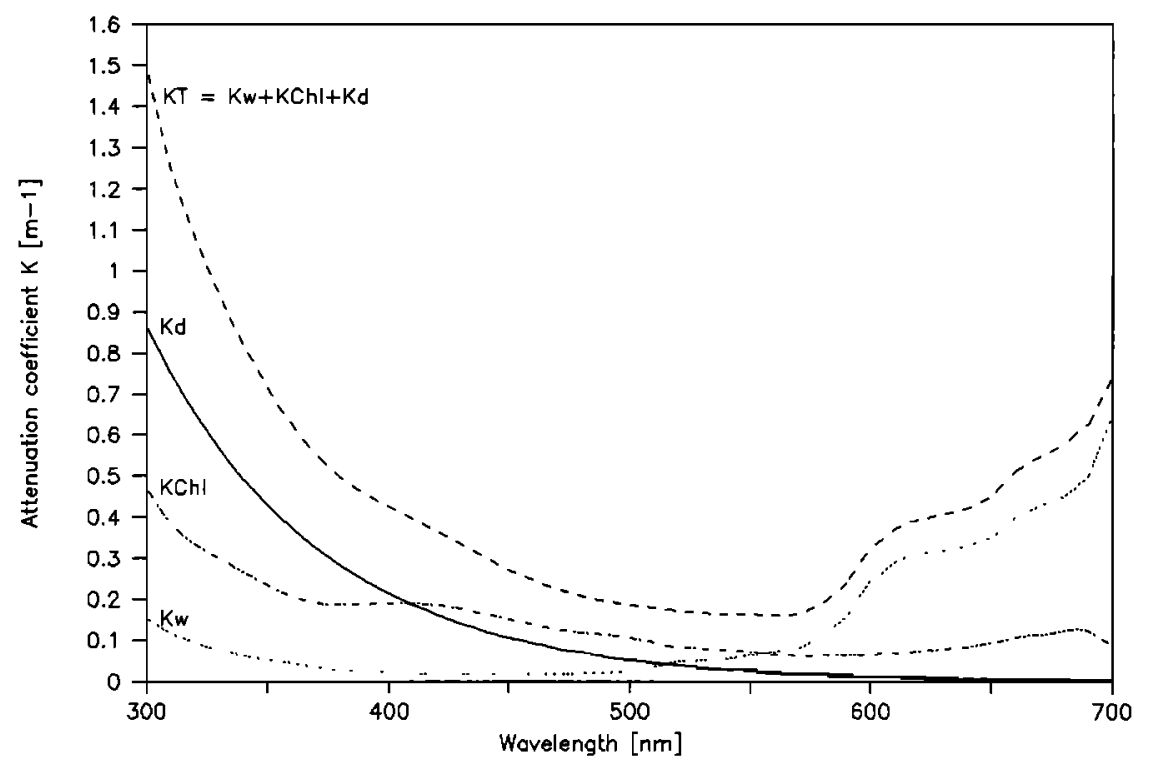

Figure 2. Light attenuation versus wavelength. KT, the total attenuation, is the sum of the attenuations of water, chlorophyll-like substances $\left(1.0 \mathrm{mg} \mathrm{m} \mathrm{m}^{-3}\right.$ ), and dissolved yellow substances (CDOC $=0.5 \mathrm{mg}$ $\mathrm{L}^{-1}$ ). As predicted by the model of Baker and Smith [1982]. CHL, chlorophyll; d, DOC; w, water; T, total.

In regressing the backscattering probability $\tilde{b}_{b}$, where $\widetilde{b}_{b}$ is the ratio of backscattering $b_{b}$ to total scattering $b$, against algal biomass, Gordon et al. [1988] found the relationship

$$
\bar{b}_{b}(\lambda)=C_{1} C^{C 2}
$$

where $C$ in milligrams per cubic meter is pigment concentration, and $C_{1}$ and $C_{2}$ are empirical coefficients. Since

$$
b_{b}(\lambda)=b \times \tilde{b}_{b}(\lambda),
$$

we obtain, for example, at $550 \mathrm{~nm}$,

$$
b_{b}(\lambda)=b^{0} C^{0.62} \times C_{1} C^{C 2}
$$

or we find that $A(\lambda)$ is approximated by

$$
A(\lambda)=b^{0} \times C_{1}
$$

Over a pigment range of $0.1-20.0 \mathrm{mg} \mathrm{chl} \mathrm{m} \mathrm{m}^{-3}$, estimates of $b^{0}$ and $A(\lambda)$ have been presented by Gordon et al. [1983, 1988] for case I and a mixture of case I and case II waters.

\subsection{Computation of CDOC Stocks}

We first computed the apparent pigment from (2) and data from the 443/550- and 520/550-nm bands of the CZCS at three geographical locations where both HPLC-determined in situ pigment and CDOC data (for 1988) were available (stations R5, M, and $\mathrm{H}$ of Figure 1). Using the CZCS estimates of algal biomass, that is, initially assuming that the apparent pigment levels in (2), (8), and (11) were correct, we then fitted Gordon et al.'s [1988] modeled radiances to the CZCS $\left[L_{w}\right]_{N}$ using a background CDOC concentration of $\sim 0.106$ mg CDOC $\mathrm{L}^{-1}$, equivalent to that of the Sargasso Sea [Gordon et al., 1988], and an appropriate $A(\lambda)$ at 443, 520, and $550 \mathrm{~nm}$ (16) for the Orinoco River plume region, which may or may not correspond to the values used by Gordon et al. [1988].

Once the values of $A(\lambda)$ were determined, we used the in situ pigment observation [Bidigare et al., 1993] in (8) rather than the satellite estimates to compute the particulate contribution to light absorption, that is, (7). CDOC values were then increased in (7), (9), and (10) to lower the computed values of $\left[L_{w}\right]_{N}$ at 443 and $520 \mathrm{~nm}$ of (5) until they matched the value of $\left[L_{w}\right]_{N}$ from the satellite. The model's CDOC concentration was then compared with Blough et al.'s [1993] observations within the Orinoco River plume.

\section{Results}

\subsection{Aerosol Correction}

Figure 3 shows the location of aerosol radiance data at 670 $\mathrm{nm}$, extracted from a CZCS image taken October 9, 1979; it was one of the images of the weekly composite shown in Plate 1 (bottom). There is no correlation in Figure 4 of the apparent pigment concentration with the average aerosol radiance at $670 \mathrm{~nm}\left(\left\langle L_{a}(670)\right\rangle\right)$, band 4). The coefficient of determination $r^{2}$ was only 0.04 for a sample size of 351 . While this figure shows the aggregate data from the three transects, this same trend was evident when each transect was examined individually. In all cases, while the pigment concentration was highest in the core and toward the river discharge, there was no such pattern for the values of $L_{a}(670)$, which were random. This suggests that there was no need for further aerosol correction, at least in offshore areas of the Orinoco River plume. Closer to shore (within $\sim 100 \mathrm{~km}$ of the delta), however, large amounts of presumed sediment complicated the interpretation of the CZCS imagery. When high radiance, which would have given erroneous results, was encountered in the CZCS data of Plate 1, a land mask was applied to exclude pixels with high levels of suspended matter from evaluation.

\subsection{Backscattering}

Within an additional image collected on September 3, 1979 , and that of October $9,1979, A(\lambda)$ values were estimated in both images for three regions (three boxes of Figure 3). Two were located in areas of high and intermediate color, 


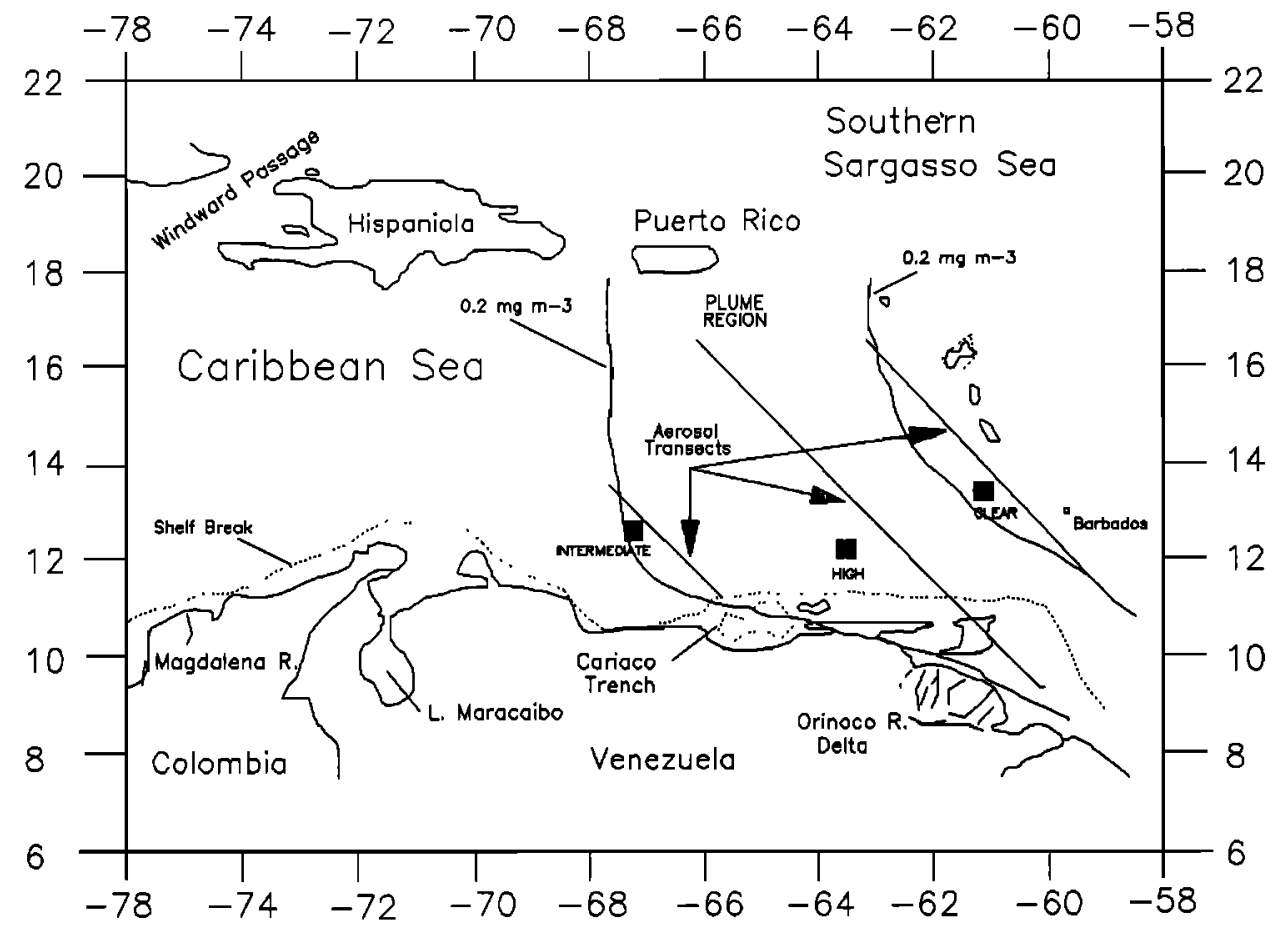

Figure 3. Location of aerosol radiance sampling transects and backscatter sampling quadrants. High, intermediate, and clear-water regions of the typical plume of the Orinoco River are indicated by CZCS estimates of apparent pigment concentrations. The edges of the plume are demarcated by the $0.2 \mathrm{mg}$ pigment $\mathrm{m}^{-3}$ isopleth.

while the third was outside of the Orinoco River plume $(<0.2$ mg pigment $\mathrm{m}^{-3}$ ). A background CDOC value of $0.106 \mathrm{mg}$ CDOC L $\mathrm{L}^{-1}$ and the $B(\lambda)$ and $\left(b_{b}\right)_{W}$ values of Gordon et al. [1988] were used at 443,520 , and $550 \mathrm{~nm}$ in (6), (10), and (11).

Figure 5 compares the observed water-leaving radiances with apparent pigment concentrations and the results of (5) at $443 \mathrm{~nm}$ for two values of $A(\lambda)$, that of Gordon et al. [1988] and the computed value. Where $C D O C$ was assumed to be low, $A(443)$ had to be reduced to $0.8 \times 10^{-3} \mathrm{~m}^{-1}$ from Gordon et al.'s [1988] mean value of $3.0 \times 10^{-3} \mathrm{~m}^{-1}$ to fit the CZCS radiance data. As a consequence, the computed

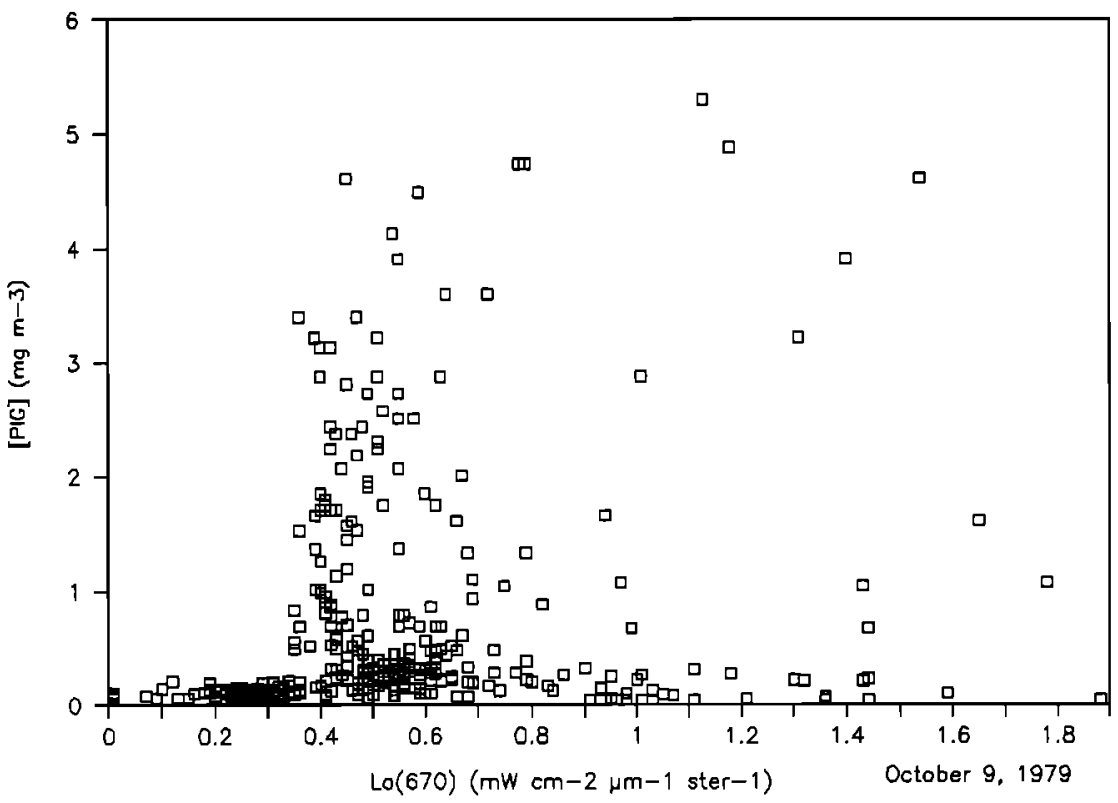

Figure 4. Aerosol radiance $(670 \mathrm{~nm})$ versus CZCS apparent pigment (PIG) concentration in the Orinoco River plume on October 9, 1979. Locations where data were obtained are shown in Figure $3(n=351$; $\left.r^{2}=0.04\right)$. 


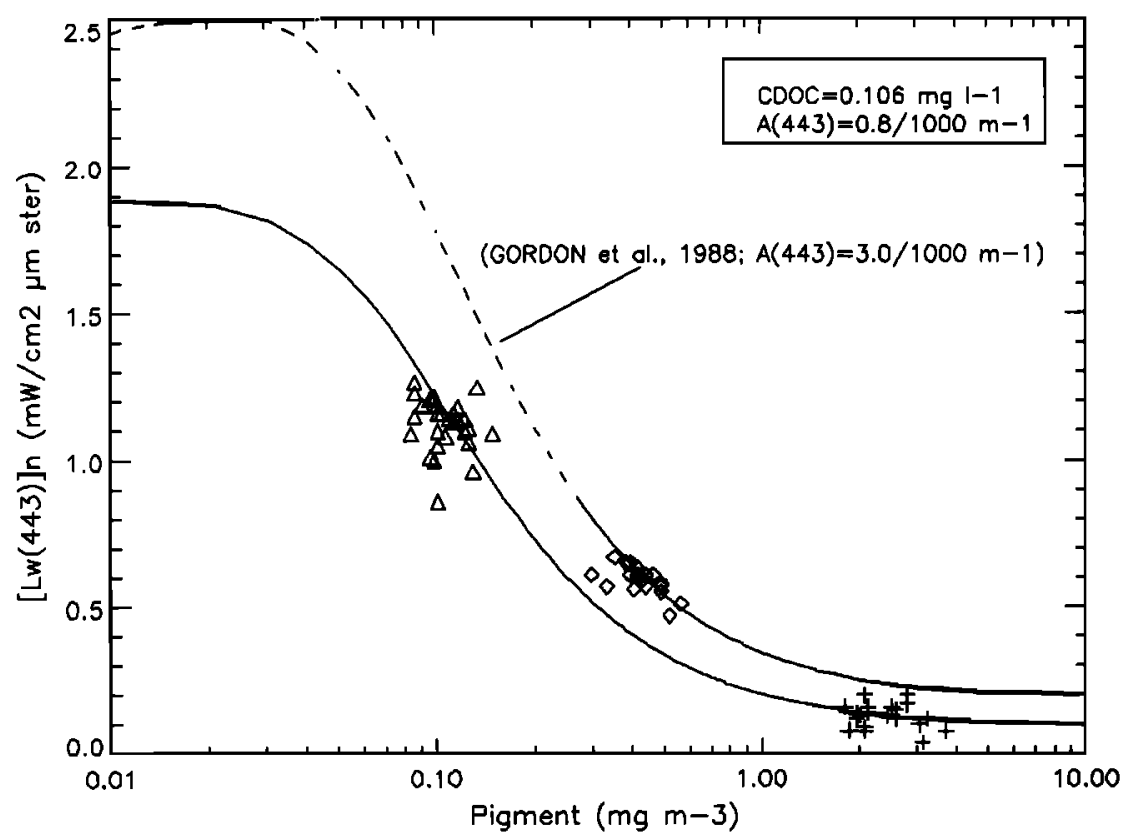

Figure 5. Normalized water-leaving radiance $\left[L_{w}(\lambda)\right]_{N}$ at $443 \mathrm{~nm}$ with various concentrations of pigment within high (plus signs), intermediate (open diamonds), and clear (open triangles) color regions of the Orinoco River plume.

water-leaving radiance decreased primarily at the low pigment concentrations, that is, outside of the plume, where one expects backscattering to be more important than light absorption. Inside the plume, where higher pigment concentrations are found, the change in $A(\lambda)$ would be less noticeable, since absorption dominates there.

At a pigment concentration of $0.10 \mathrm{mg} \mathrm{m}^{-3}$ in Figure 5, for example, the calculated $\left[L_{w}(\lambda)\right]_{N}$ decreased from the approximately $1.8 \mathrm{~mW} \mathrm{~cm} \mathrm{~cm}^{-1} \mathrm{sr}^{-1}\left(b^{0}=0.3 \mathrm{~m}^{-1}\right)$ of
Gordon et al. [1988] to $1.1 \mathrm{~mW} \mathrm{~cm}^{-2} \mu \mathrm{m}^{-1} \mathrm{sr}^{-1}\left(b^{0}=0.08\right.$ $\mathrm{m}^{-1}$ ). This corresponds to a reduction in $A(443)$ from $3.0 \times$ $10^{-3} \mathrm{~m}^{-1}$ to $0.8 \times 10^{-3} \mathrm{~m}^{-1}$. In Figure 6 , for the $520-\mathrm{nm}$ band, a value for $A(520)$ of $2.5 \times 10^{-3} \mathrm{~m}^{-1}$ modeled the radiance data well, but again, a lower value of $A(520)$ was required than the $3.3 \times 10^{-3} \mathrm{~m}^{-1}$ from the Gordon et al. [1988] analysis for the Sargasso Sea. Similarly, for the 550-nm band in Figure 7, a smaller value, $1.7 \times 10^{-3} \mathrm{~m}^{-1}$, was used for $A(550)$ instead of the $3.3 \times 10^{-3} \mathrm{~m}^{-1}$ from Gordon et al. [1988].

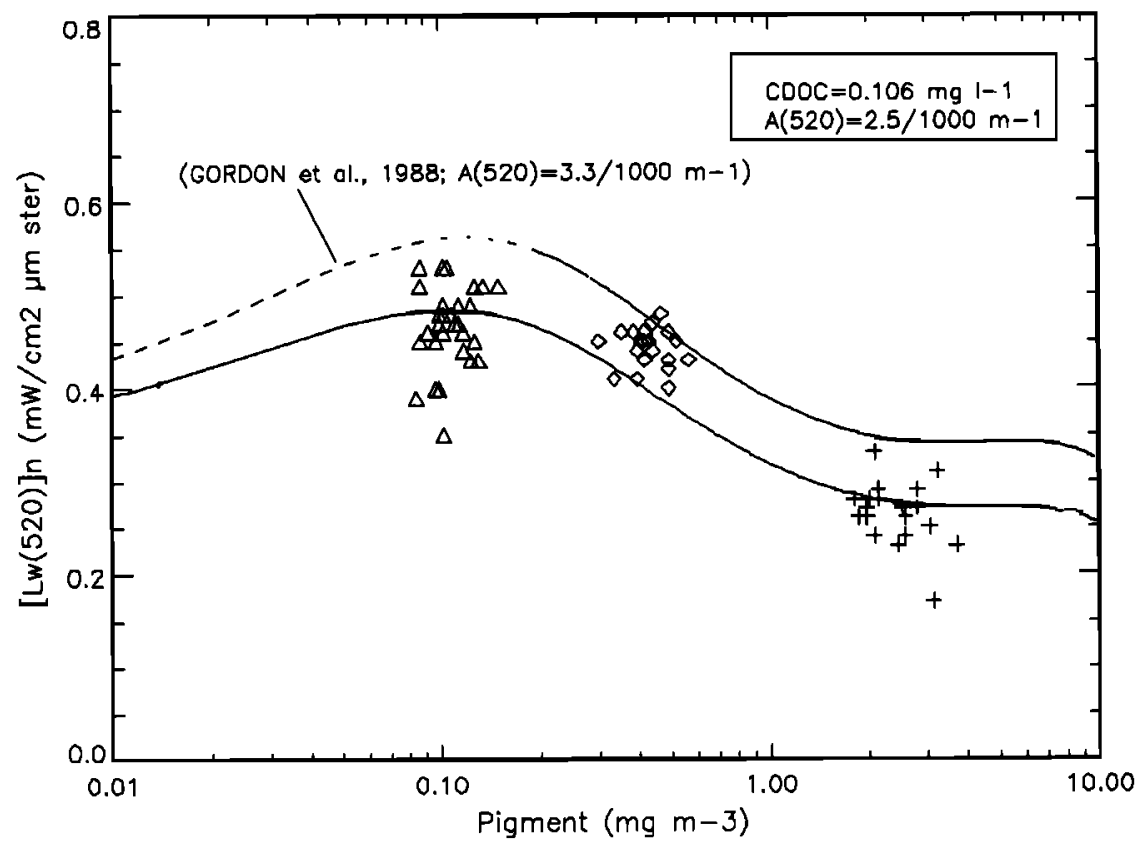

Figure 6. Normalized water-leaving radiance $\left[L_{w}(\lambda)\right]_{N}$ at $520 \mathrm{~nm}$ with various concentrations of apparent pigment within high (plus signs), intermediate (open diamonds), and clear (open triangles) color regions of the Orinoco River plume. 


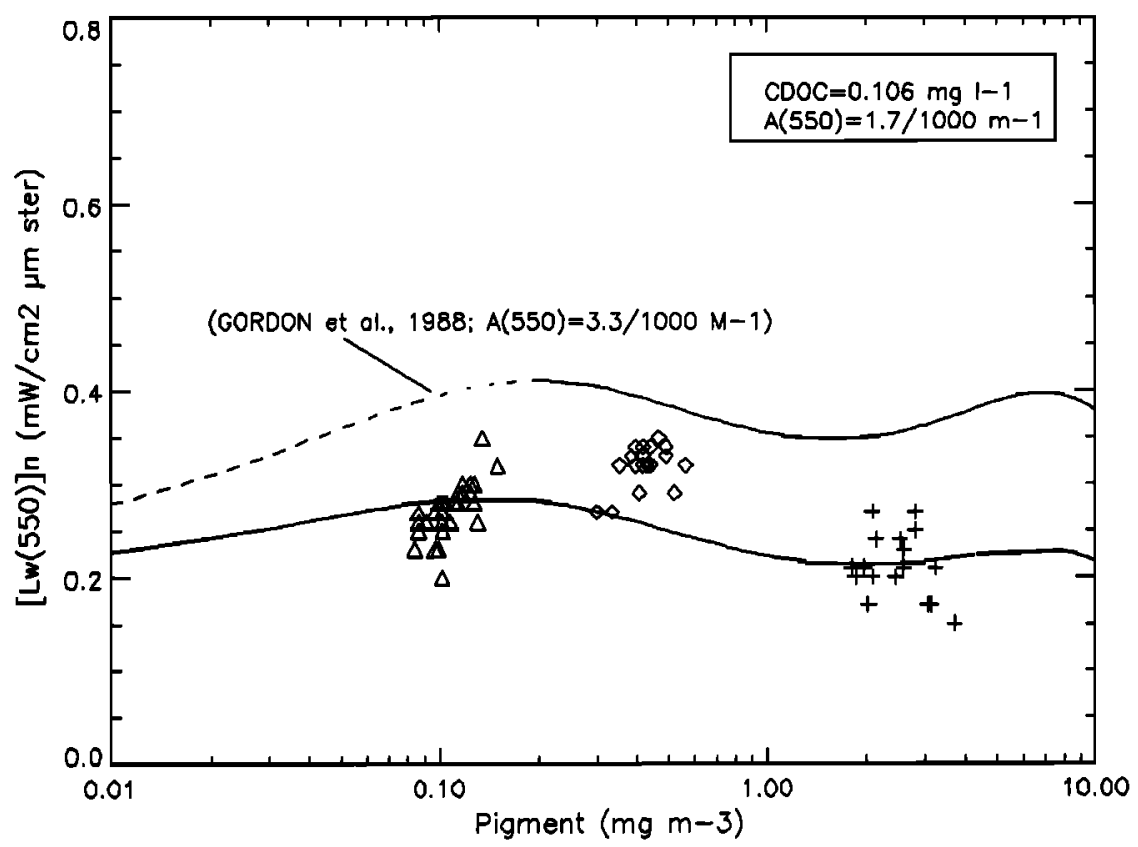

Figure 7. Normalized water-leaving radiance $\left[L_{w}(\lambda)\right]_{N}$ at $550 \mathrm{~nm}$ with various concentrations of pigment within high (plus signs), intermediate (open diamonds), and clear (open triangles) color regions of the Orinoco River plume.

A number of biotic conditions can have an effect on backscattering of light in the sea. For example, at low pigment concentrations, increased backscattering may be due to the influence of detrital material and/or bacteria [Ulloa et al., 1992]. Since the changes in $\left[L_{w}(\lambda)\right]_{N}$ of Figures 5, 6, and 7 indicated backscattering conditions resulting in $A(\lambda)$ values lower than that of Gordon et al. [1988], it is concluded that this oceanic region may not be representative of the region described by the Gordon et al. [1988] curves. As was mentioned before, this could mean differences in concentrations of chlorophyll, coccolithophores, or bacteria or simply changes in species composition [Balch et al., 1989], which would cause an under- or overestimate of chlorophyll biomass. While the Gordon et al. [1988] model is used for case I as well as for a mixture of case I and case II waters, this exercise suggests that it may also may be used for case II waters.

\subsection{CDOC Stocks}

Figures \&-10 show the results of our attempt to estimate CDOC stocks at stations $\mathrm{M}, \mathrm{H}$, and $\mathrm{R} 5$ along the axis of the Orinoco River plume (Figure 1). Table 1 gives in situ and
CZCS-derived values of pigment for the three sites. At station $M$ (Figure 1), for example, about $423 \mathrm{~km}$ downstream of the river mouth, an arbitrary CDOC amount of $0.20 \mathrm{mg}$ $\mathrm{L}^{-1}$ was added to $(9)$ and $(10)$, with an in situ pigment value of $0.75 \mathrm{mg} \mathrm{m}^{-3}$ in (8) and an $A(520)$ of $2.5 \times 10^{-3} \mathrm{~m}^{-1}$ to lower the radiance from the computed value of $\left[L_{w}(520)\right]_{N}$ at point $X$ (Figure 8), derived from a CZCS pigment determination of $1.33 \mathrm{mg} \mathrm{chl} \mathrm{m}{ }^{-3}$, an $A(\lambda)$ of $3.3 \times 10^{-3} \mathrm{~m}^{-1}$, and an assumed CDOC stock of $0.106 \mathrm{mg} \mathrm{L}^{-1}$, to the observed radiance value at point $Y$. The "predicted" CDOC concentration is about one third of the measured CDOC of $0.6 \mathrm{mg} \mathrm{L}^{-1}$ [Blough et al., 1993].

The relative contributions to attenuation by the three components of (7) were calculated for station $M$. While Figure 8 represents only $\left[L_{w}(520)\right]_{N}$, the calculation was done for both 520 and $443 \mathrm{~nm}$. CDOC attenuation at $443 \mathrm{~nm}$ is $11 \%$ of $K_{T}$ at point $\mathrm{X}$ compared to $24 \%$ of $K_{T}$ at $\mathrm{Y}$, that is, more than the attenuation of the observed pigments [Bidigare et al., 1993]. In contrast, for station $M$ at $520 \mathrm{~nm}$ (Figure 8), the CDOC attenuation in (7) is $5 \%$ of $K_{T}$ at X compared to $12 \%$ of $K_{T}$ at $\mathrm{Y}$; differences are expected

Table 1. Levels of Salinity, in Situ CDOC and Pigments, and CZCS Pigments

\begin{tabular}{crcccccc}
\hline Station & Latitude & Longitude & $\begin{array}{c}\text { [CDOC], } \\
\text { Measured }\end{array}$ & $\begin{array}{c}\text { [PIG], } \\
\text { Measured } \dagger\end{array}$ & $\begin{array}{c}\text { Salinity, } \\
\text { psu }\end{array}$ & $\begin{array}{c}\text { [PIG], } \\
\text { CZCS }\end{array}$ & $\begin{array}{c}\text { [CDOC], } \\
\text { Calculated }\end{array}$ \\
\hline R5 & $8^{\circ} 37^{\prime} \mathrm{N}$ & $6^{\circ} 29^{\prime} \mathrm{W}$ & 2.5 & 0.48 & 7.5 & 3.17 & NA \\
$\mathrm{M}$ & $11^{\circ} 48^{\prime} \mathrm{N}$ & $6^{\circ} 45^{\prime} \mathrm{W}$ & 0.6 & 0.75 & 30.5 & 1.33 & 0.2 \\
$\mathrm{H}$ & $14^{\circ} 40^{\prime} \mathrm{N}$ & $6^{\circ} 45^{\prime} \mathrm{W}$ & 0.2 & 0.30 & 33.6 & 0.61 & 0.7 \\
\hline
\end{tabular}

Values are from three stations sampled by Blough et al. [1993] and Bidigare et al. [1993] along the axis of the Orinoco River plume during the rainy season. Pigments are chlorophyll $a$ plus phaeopigments. PIG, pigment; NA, not applicable.

*In milligrams per liter.

†In milligrams chlorophyll per cubic meter. 


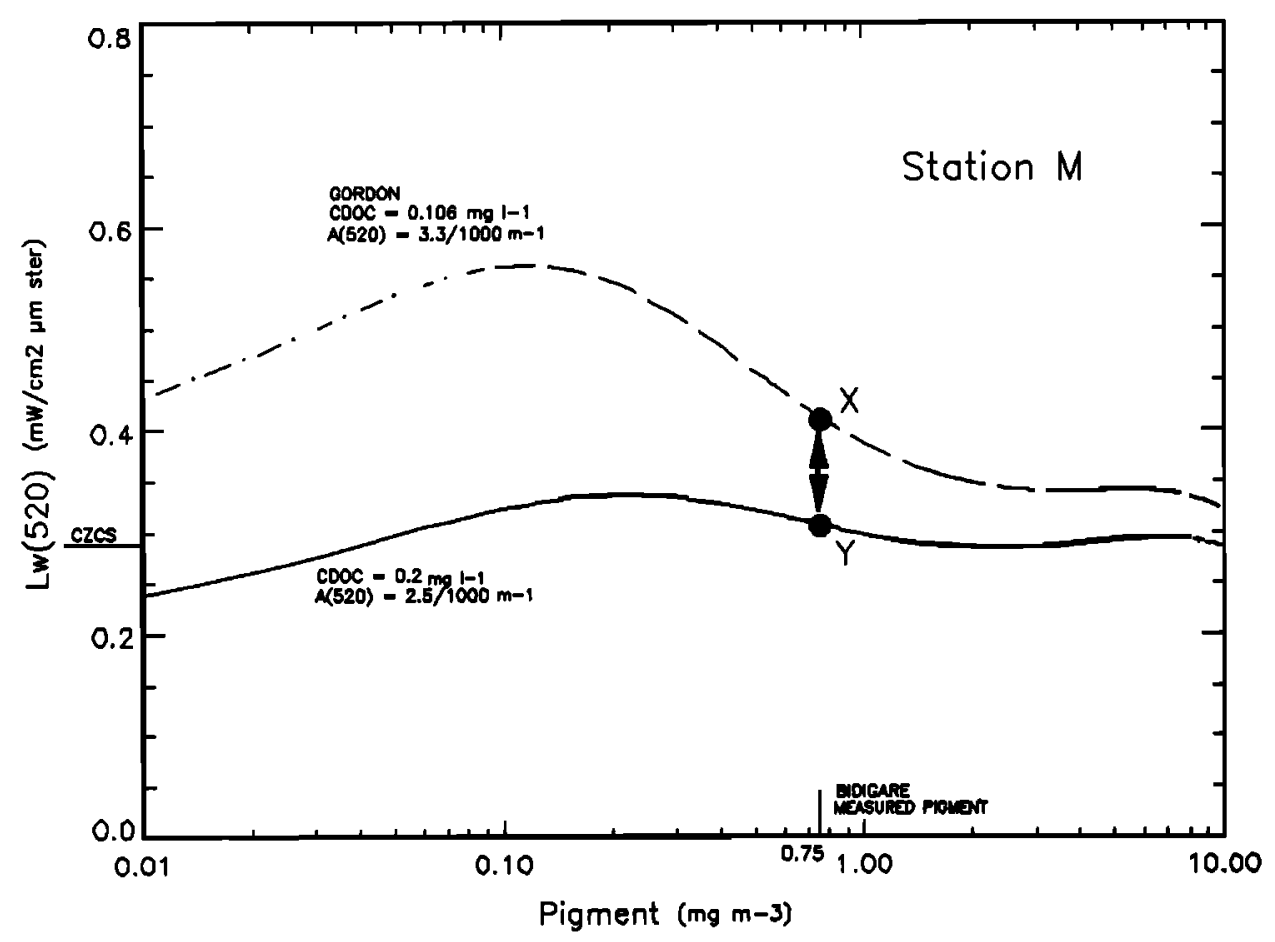

Figure 8. An analysis of the computed CDOC required at station $M$ to match the CZCS water-leaving radiance at $520 \mathrm{~nm}$ for an in situ value of pigment [Bidigare et al., 1993] and an $A(\lambda)$ of $2.2 \times 10^{-3} \mathrm{~m}^{-1}$. A similar curve, with a background level of CDOC and an $A(\lambda)$ of $3.3 \times 10^{-3} \mathrm{~m}^{-1}$ [Gordon et al., 1988], is also shown.

between these wavelengths, because at similar values, $K_{y s}$ is more important than $K_{C}$ of shorter wavelengths (Figure 2).

Station $H$ was located another $370 \mathrm{~km}$ farther downstream. A computed CDOC stock of $0.7 \mathrm{mg} \mathrm{L}^{-1}$ was required here (Figure 9) to lower $\left[L_{w}(443)\right]_{N}$ from point $X$ to $Y$ with an $A(\lambda)$ of $0.8 \times 10^{-3} \mathrm{~m}^{-1}$ and an in situ pigment concentration of $0.30 \mu \mathrm{g} \mathrm{L} \mathrm{L}^{-1}$. Here, the CDOC contribution to light attenuation at $443 \mathrm{~nm}$ might be $17 \%$ of $K_{T}$ at point $X$ compared to $72 \%$ of $K_{T}$ at $Y$, that is, again more than the absorption of the phytoplankton pigments. However, Blough et al. [1993] measured a concentration of only $0.2 \mathrm{mg}$ CDOC $\mathrm{L}^{-1}$ in 1988 at station $\mathrm{H}$. At this lower pigment concentration, the water-leaving radiance can be retrieved with greater accuracy using the 443-nm band.

At this greater distance down the axis of the Orinoco River plume, anticyclonic eddies were observed in the 1979 satellite observations (Plate 1). These eddies, as well as variabilities in plume path, may generate greater patchiness in the offshore distribution of river water within the basin, so that these interannual comparisons of computed and observed CDOC (and chl) may be more difficult to make downstream in the river plume.

Similarly, at the landward boundary of the plume near station R5 (Figure 1), optical properties are complex. The observed $\left[L_{w}(520)\right]_{N}$ value of $1.53 \mathrm{~mW} \mu \mathrm{m}^{-1} \mathrm{~cm}^{-2} \mathrm{sr}^{-1}$ at point $Y$ actually exceeds the value at point $X$ predicted from the Gordon et al. [1988] model background of $0.106 \mathrm{mg}$ CDOC $\mathrm{L}^{-1}$, a pigment value of $3.17 \mathrm{mg} \mathrm{m}^{-3}$ (Table 1), and an $A(\lambda)$ of $3.3 \times 10^{-3} \mathrm{~m}^{-1}$ by over $1 \mathrm{~mW} \mu \mathrm{m}^{-1} \mathrm{~cm}^{-2} \mathrm{sr}^{-1}$ (Figure 10). Utilizing the observed values of $2.5 \mathrm{mg}$ CDOC $\mathrm{L}^{-1}$ and $0.48 \mathrm{mg}$ pigment $\mathrm{m}^{-3}$ with an $A(\lambda)$ of $2.5 \times 10^{-3}$ $\mathrm{m}^{-1}$ makes matters worse, with a lower value at point $\mathrm{Z}$. We presume that these discrepancies result from excessive backscatter by nearshore sediment and/or bottom reflection (water depths here are less than $50 \mathrm{~m}$ ). These factors are considered in (5) and (6), which point out future requirements for studies of case II coastal waters at river mouths.

\section{Discussion}

The observed values of water-leaving radiance in Figures 8-10 are the confounded result of backscatter and absorption by particles and dissolved materials. Further, the sources of CDOC may have a profound impact on the optical properties of the Orinoco River plume. As a consequence of different molecular structures, terrestrial and marine humus have unique specific absorption coefficients $\boldsymbol{k}_{d}$ [Morel and Prieur, 1977; Harvey et al., 1983; Brown, 1987; Carder et al., 1989].

Since dissolved organic matter shows an exponential increase in absorption at shorter wavelengths (Figure 2), the spectral dependence of $k_{d}$ in (10) can be described [Bricaud et al., 1981] by

$$
k_{d}(\lambda)=k_{d}\left(\lambda_{0}\right) \exp \left[S\left(\lambda_{0}-\lambda\right)\right]
$$

where $S$ is the spectral slope coefficient (reciprocal nanometers), allowing $k_{d}(\lambda)$ to be derived for any wavelengtt. The slope of the spectral absorption curve is thought to provide a measure of the relative fractions of fulvic and humic acids in the CDOC [Carder et al., 1989], while the value of $k_{d}$ may be a function of the molecular weights of terrestrial and marine CDOC.

Blough et al. [1993], for example, obtained a $k_{d}(375)$ of $3.70 \mathrm{~L} \mathrm{mg}^{-1} \mathrm{~m}^{-1}$ at station $\mathrm{M}\left(\sim 12^{\circ} \mathrm{N}, 63^{\circ} \mathrm{W}\right)$, with a salinity 


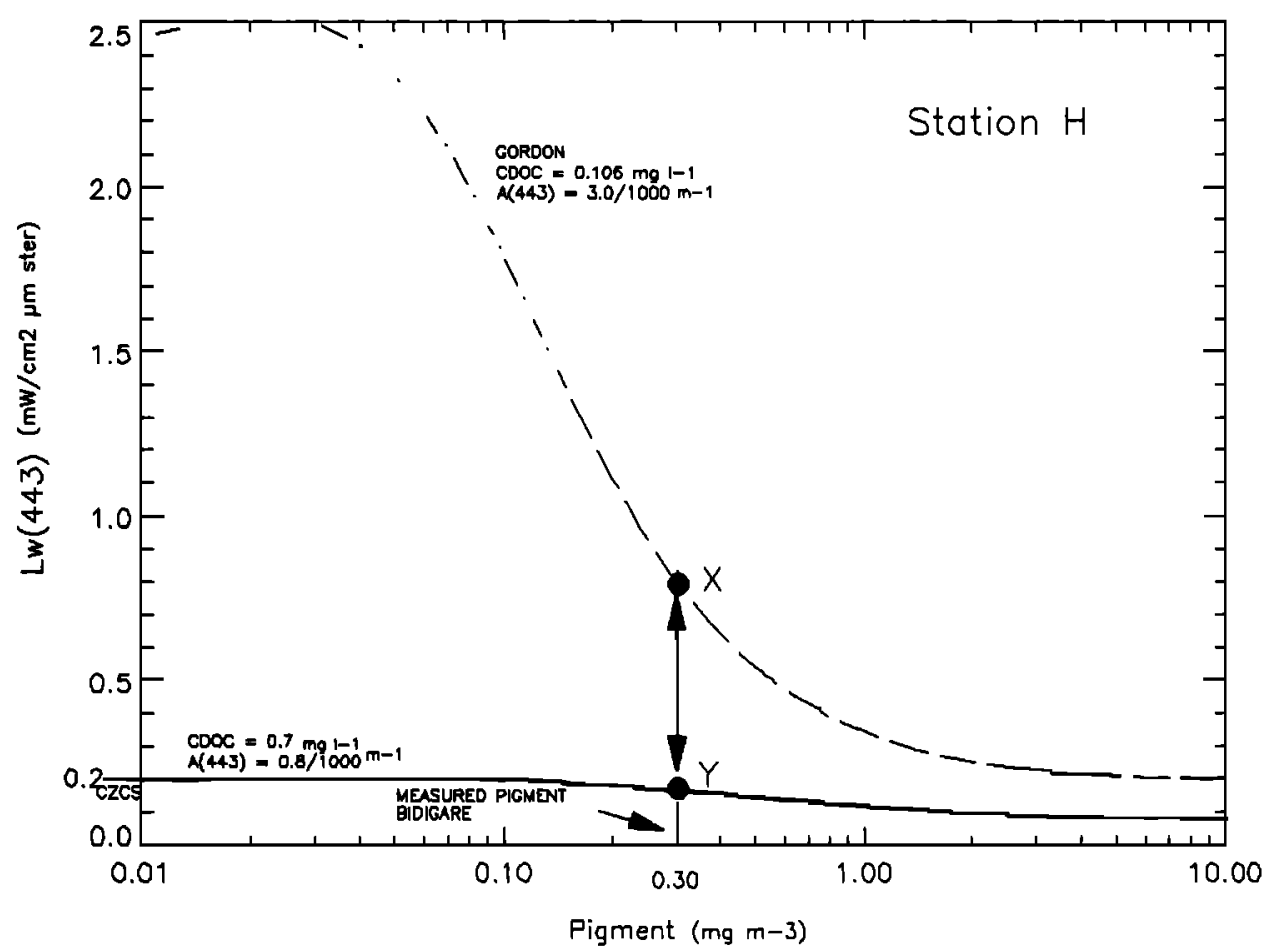

Figure 9. An analysis of the computed CDOC required at station $\mathrm{H}$ to match the CZCS water-leaving radiance at $443 \mathrm{~nm}$ for an in situ value of pigment [Bidigare et al., 1993] and an $A(\lambda)$ of $0.8 \times 10^{-3} \mathrm{~m}^{-1}$. A similar curve, with a background level of CDOC and an $A(\lambda)$ of $3.3 \times 10^{-3} \mathrm{~m}^{-1}$ [Gordon et al., 1988], is also shown.

of 33 practical salinity units (psu) (Figure 11). In contrast, Carder et al. [1989] measured a $k_{d}(375)$ of $0.15 \mathrm{~L} \mathrm{mg}^{-1} \mathrm{~m}^{-1}$ at -25 psu (Figure 11) near station $A$ at the mouth of the Mississippi River $\left(\sim 29^{\circ} \mathrm{N}, 89^{\circ} \mathrm{W}\right)$. This disparity at similar salinities led Blough et al. [1993] to conclude that the CDOC in the Orinoco River plume was mainly of terrestrial origin, whereas the CDOC of the Mississippi River plume was mainly from a marine source [Carder et al., 1989].

The chlorophyll stocks were about 0.8 and $8.0 \mu \mathrm{g} \mathrm{L}-1$ at stations $\mathbf{M}$ and $\mathbf{A}$ within the Orinoco and Mississippi River plumes, respectively. The higher values of DOC and CDOC at station $\mathrm{B}$ on the west Florida shelf (Figure 11) are associated with a senescent phytoplankton bloom [Carder et al., 1989], similar perhaps to the plankton dynamics at station R5. The optical properties of the same amount of CDOC stocks at stations $\mathrm{H}$ and $\mathrm{C}$ in the Caribbean and Gulf of Mexico basins are quite different, however, as a result of the proposed origin of the dissolved organic matter.

The spectral slopes $S$ are also different: 0.014 and 0.0194 $\mathrm{nm}^{-1}$ (Figure 12), reflecting possible differences in the humic and fulvic acid components of CDOC within the Orinoco and Mississippi River plumes, respectively [Blough et al., 1993; Carder et al., 1989].

While only the fulvic acid absorption was measured at station A near the mouth of the Mississippi River [Carder et al., 1989], the curve of Figure 12 was constructed using $85 \%$ of the Mississippi River fulvic acid estimate and $15 \%$ of the Loop Current humic acid value at offshore station C (Figure 11). A humic:fulvic acid ratio of 40:60 may be more applicable for the terrigenous case (K. Carder, personal communication, 1993).

As a consequence of (9) and (10), the products of a constant CDOC stock and various specific absorption coefficients $k_{d}\left(\lambda_{0}\right)$ partially affect the value of $\left[L_{w}(\lambda)\right]_{N}$. The bio-optical model of Gordon et al. [1988], for example, assumed a background absorption $\alpha_{y s}(375)$ of $0.06 \mathrm{~m}^{-1}$, corresponding to a CDOC of $0.106 \mathrm{mg} \mathrm{L}^{-1}$ and a $k_{d}(375)$ of $0.565 \mathrm{~L} \mathrm{mg} \mathrm{m}^{-1}$. As a result, $K_{y s}(443)$ is $0.0 \mathrm{~m}^{-1}$ in (9) as well as at all other wavelengths, such that the computed $\left[L_{w}(443)\right]_{N}$ from (5) is maximal at any value of $K_{C}$ and $A(443)$ (recall Figures 8-10).

Any change in the product of CDOC and $k_{d}\left(\lambda_{0}\right)$ which yields $K_{y s}(375)$ greater than zero results in a decrease of the computed $\left[L_{w}(443)\right]_{N}$, as shown in Figure 13. Here, the spectral absorption coefficient of CDOC from Blough et al. [1993] effects smaller $\left[L_{w}(443)\right]_{N}$, particularly at pigment values of $<1 \mu \mathrm{g} \mathrm{L}^{-1}$, compared to those based on either the Carder et al. [1989] or the Gordon et al. [1988] parameters (Figure 13). One might infer that the relict CDOC of oceanic water reflects more of a terrestrial origin than a marine origin in Figure 13; more data are obviously required.

\section{Summary and Conclusion}

A combination of coastal upwelling offshore of the Orinoco River delta and freshwater discharge provides sufficient nutrients for a fall phytoplankton bloom to be detected by the CZCS as far as Puerto Rico [Yoshioka et al., 1985]. However, at algal biomasses of $\leq 1.5 \mathrm{mg}$ chlorophyll $\mathrm{m}^{-3}$, as much as $50 \%$ of the color signal may be attributed to the light absorption by $\mathrm{CDOC}$ rather than to diatom populations of relatively low backscatterers. An examination of the Orinoco River plume region indicates that no additional atmospheric corrections may be required for downplume case II 


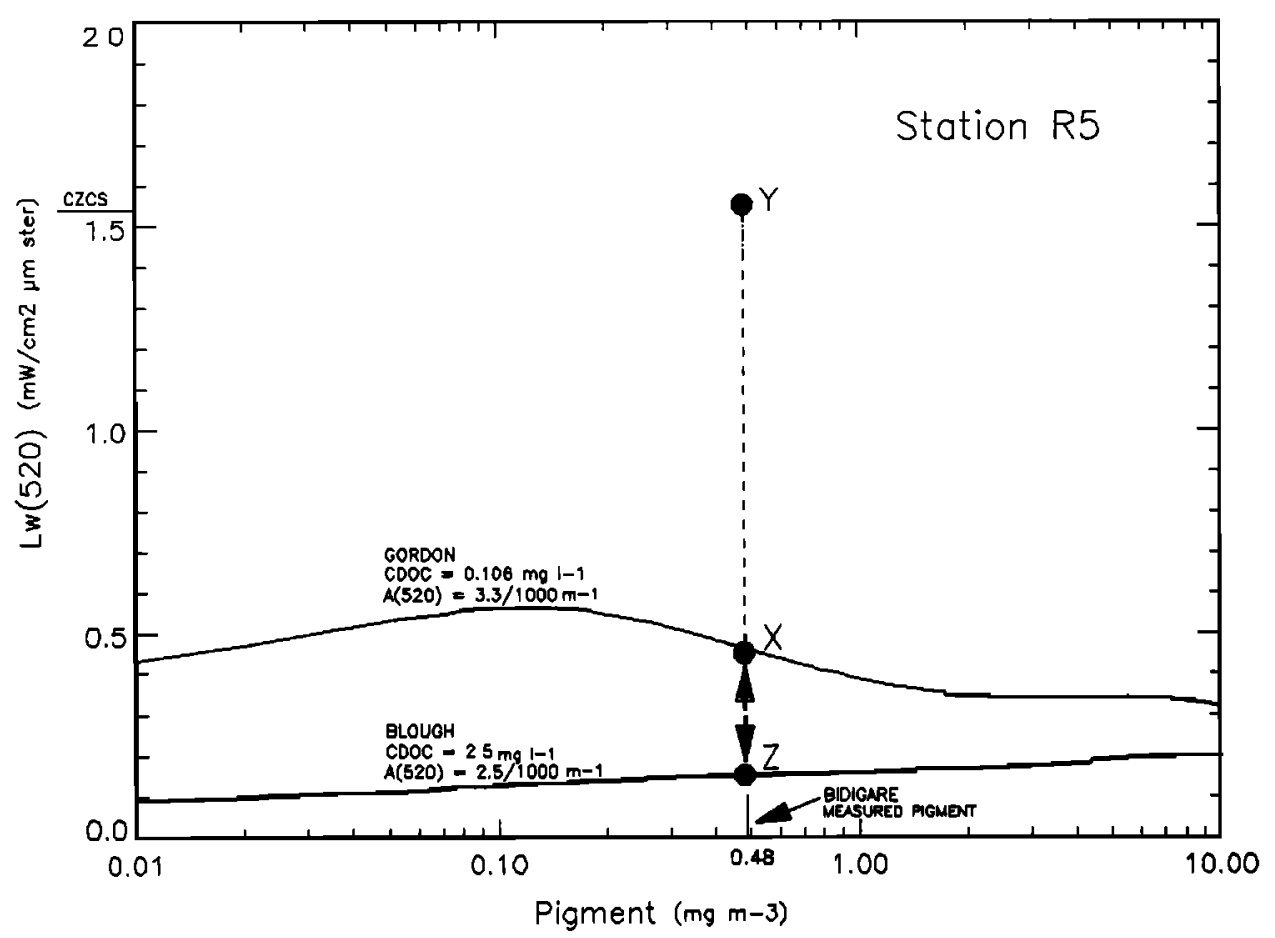

Figure 10. An analysis of the computed CDOC required at station R5 to match the CZCS water-leaving radiance at $520 \mathrm{~nm}$ for a measured value of pigment [Bidigare et al., 1993] and an $A(\lambda)$ of $2.2 \times 10^{-3} \mathrm{~m}^{-1}$. A similar curve, with a background level of CDOC and an $A(\lambda)$ of $3.3 \times 10^{-3} \mathrm{~m}^{-1}$ [Gordon et al., 1988], is also shown. The $X$ and $Z$ points are computed values of radiance, while $Y$ is observed by the CZCS. Other data are from Blough et al. [1993].

waters, but anomalously high-radiance waters are observed near the river mouth. Although almost 10 years had transpired between the CZCS and shipboard observations [Blough et al. , 1993; Bidigare et al., 1993], the interannual variation of computed and in situ estimates of CDOC stocks of the midplume region were not unreasonable.

Absorption and scattering of light by time-dependent, spatially variant particulate and dissolved materials are the

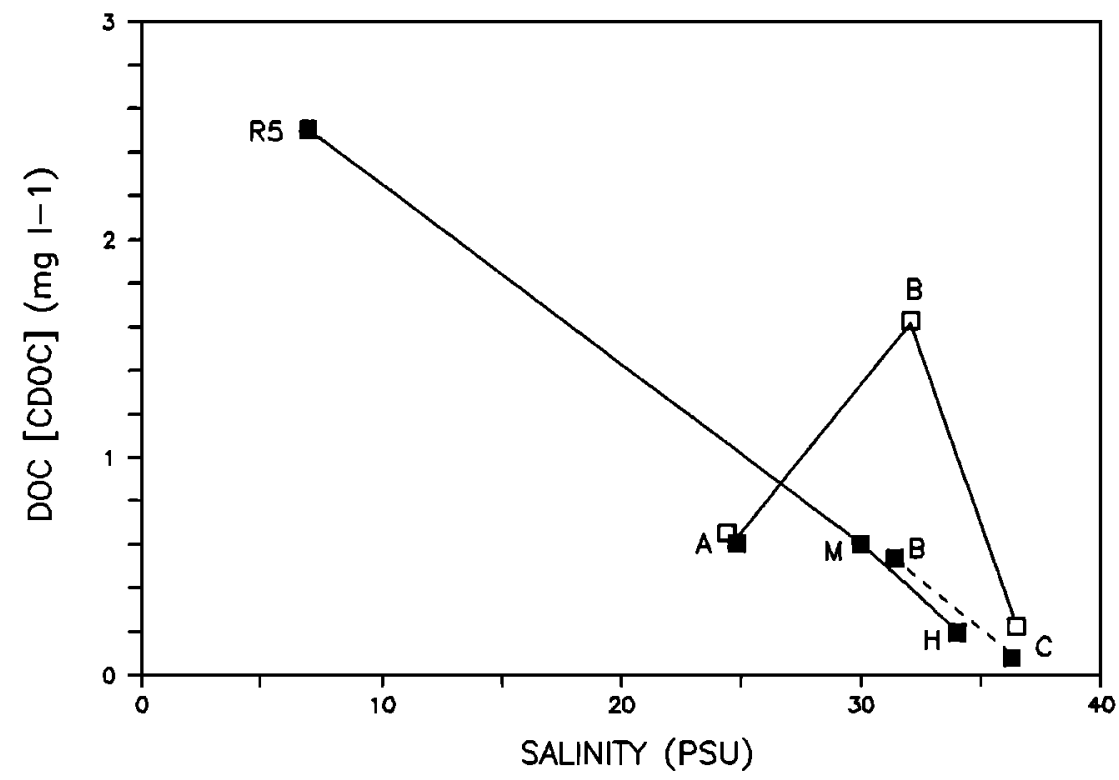

Figure 11. CDOC (solid squares) and DOC (open squares) versus salinity within the Orinoco (R5-H) and Mississippi (A-C) River plumes [after Blough et al., 1993; Harvey et al., 1983; Carder et al., 1989]; the dotted line between B and C has the same slope of CDOC as that between R5 and M. Station A is located at the mouth of the Mississippi River, station B is on the West Florida Shelf off Cape San Blas, and station $\mathrm{C}$ is within the offshore Loop Current. 


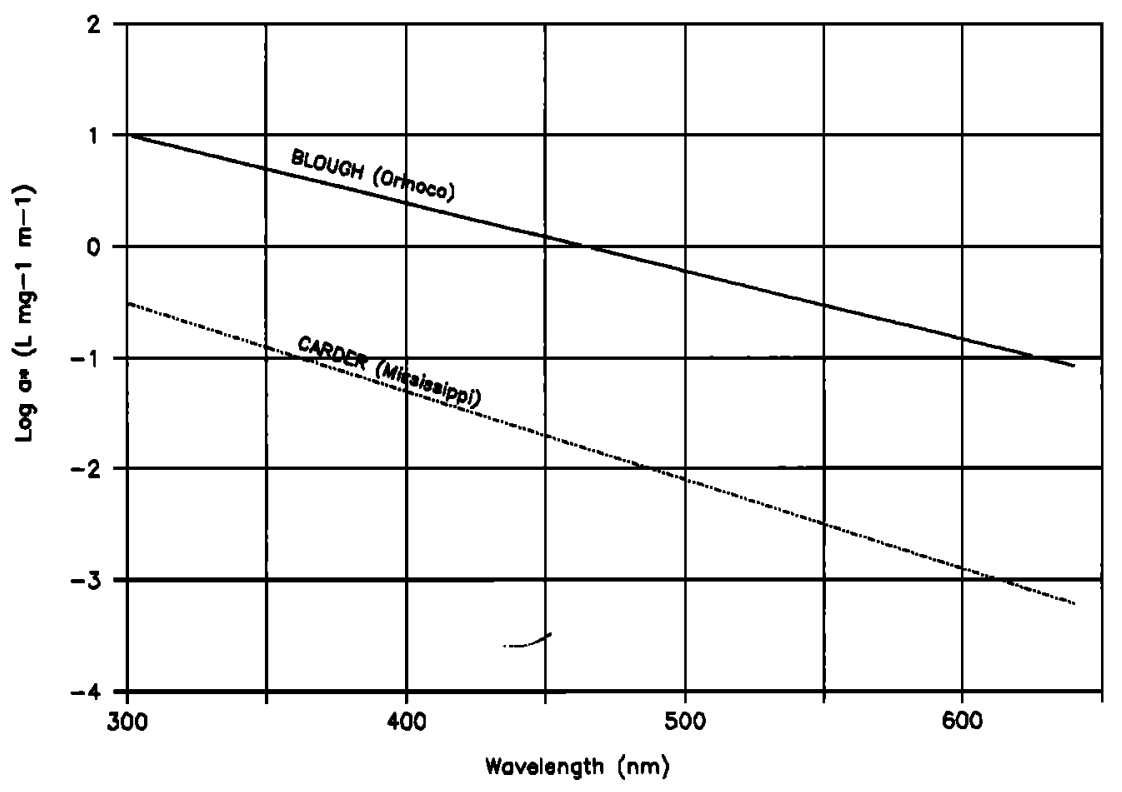

Figure 12. The specific absorption coefficients of CDOC versus wavelength, $k_{d}(\lambda)$, within the Orinoco and Mississippi River plumes. The Mississippi curve assumes a humic:fulvic ratio of 15:85 [after Blough et al., 1993; Carder et al., 1989].

parameters which determine the water-leaving radiance $L_{w}$. The blue region of the spectrum is more sensitive to backscattering at low phytoplankton concentrations, while algal pigments at higher population levels strongly influence absorption. However, the presence of CDOC in case II water confounds the relationship between pigment absorption and
$L_{w}$ at the shorter wavelengths, while species succession alters backscattering.

Modifications were thus made in our study to the "standard" CZCS bio-optical model [Gordon et al., 1988]. The backscatter values, that is, through $A(\lambda)$ of their bio-optical model, were modified for the three CZCS bands at 443, 520,

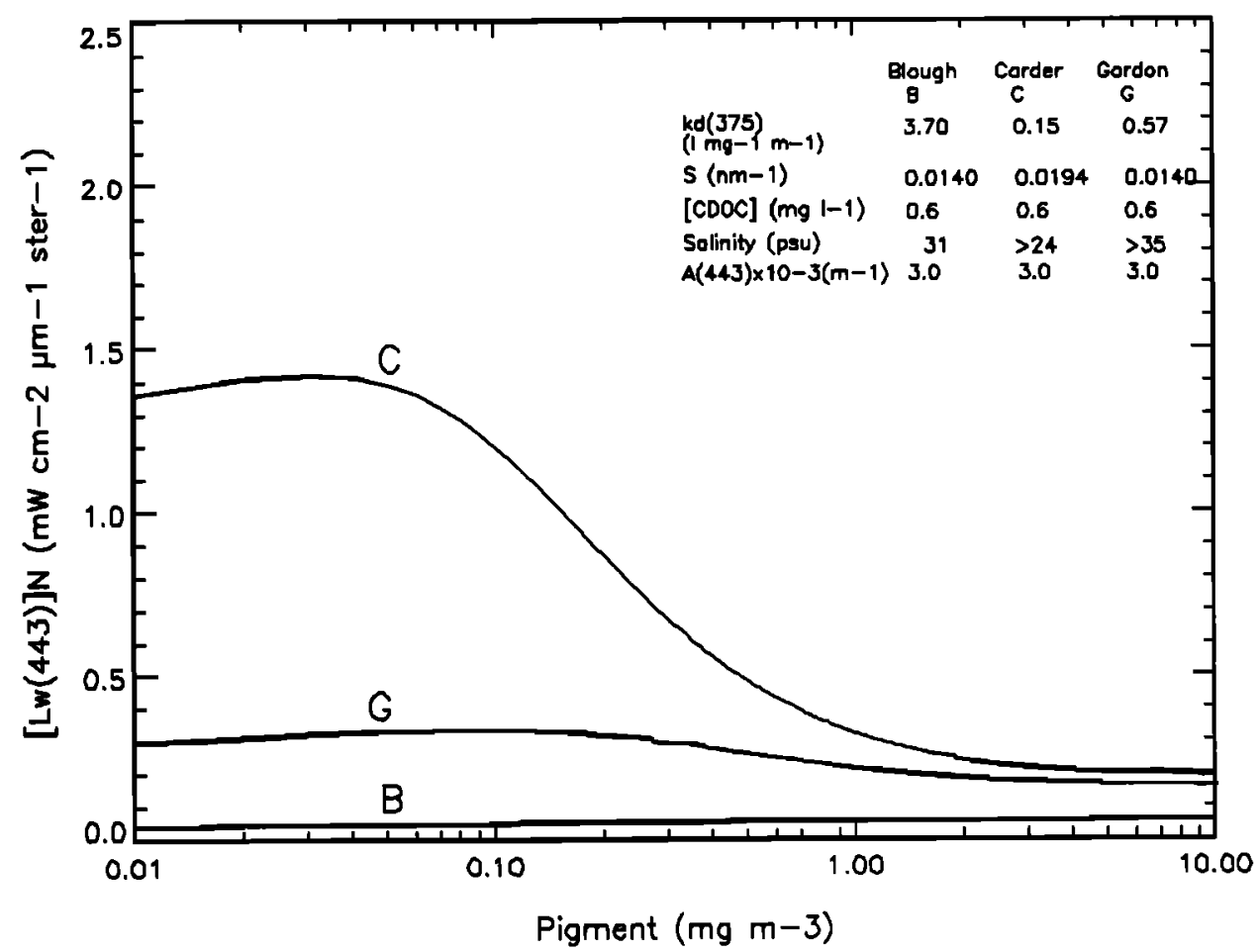

Figure 13. The consequences of different specific absorption coefficients and spectral slopes at equal concentrations of CDOC for water-leaving radiances sensed by the CZCS or sea-viewing wide-field-ofview sensor (SeaWiFS) at $443 \mathrm{~nm}$ and computed from the bio-optical model of Gordon et al. [1983] within oligotrophic habitats of (curve B) the southeastern Caribbean Sea, (curve C) the northern Gulf of Mexico, and (curve $\mathbf{G}$ ) the Sargasso Sea. 
and $550 \mathrm{~nm}$. Typically, the $A(\lambda)$ values were reduced, which lowered $\left[L_{w}(\lambda)\right]_{N}$. This could imply greater radianceabsorbing components existing in the fall plume waters than Gordon et al.'s [1988] model indicates. Dominance of diatoms during the rainy season [Bidigare et al., 1993] may also have altered the backscattering properties of otherwise oligotrophic Caribbean water in and adjacent to the Orinoco River plume.

To evaluate the amount of CDOC contamination of the apparent pigment signal, the $\left[L_{w}(\lambda)\right]_{N}$ derived from the backscattering adjustment to Gordon et al.'s [1988] model was then matched to the $\left[L_{w}(\lambda)\right]_{N}$ sampled by the CZCS. We used the in situ pigment measurements from 1988 [Bidigare et al., 1993] and varied the CDOC stocks of the model. For station $M$, in the middle of the plume, the computed CDOC was about one third the in situ observations [Blough et al., 1993]. In the case of station H, near the downstream boundary of the plume, the computed CDOC exceeded the in situ measurements by approximately a factor of 3. This may be attributed to interannual variability of the physical habitat, as the plume is dispersed. For station R5, near the upstream boundary of the plume, it was concluded that nearshore sediment may have scattered the light, thereby invalidating the model's structure. These results suggest that future refinements of the bio-optical model as well as a better description of the physical habitat are required. We next examined the possible effects of CDOC of terrestrial and marine origins as well as the composition of humic substances on CDOC modulation of water-leaving radiances. Values of the specific absorption coefficient $k_{d}(\lambda)$ from the Orinoco and Mississippi River plumes [Blough et al., 1993; Carder et al., 1989] were compared to that employed for general oceanic waters [Gordon et al., 1988]. With the same values of CDOC and $A(\lambda)$, extant estimates of $k_{d}(\lambda)$ markedly change the modeled water-leaving radiance.

Our analysis points out a number of problems that need to be addressed if satellite imagery is to continue to be a viable tool for biogeochemical studies of the ocean. Current biooptical models may not be used quantitatively for case II waters until the algorithms are updated to deal with both unspecified backscatterers and the relative absorptive qualities of chlorophyll and CDOC stocks [Walsh et al., 1992]. Of particular importance is the different specific absorption coefficients of both phytoplankton functional groups and CDOC of marine and terrestrial origins. To obtain more accurate results, it will also be necessary to incorporate information on phaeopigments, patchiness of the physical environment, and dust and sediment conditions as well as bacterial scattering and algal species succession in future analyses of riverine interactions on the continental margin.

Acknowledgments. This analysis was supported with funds from NASA grant NAGW-678.

\section{References}

Baker, K. S., and R. C. Smith, Bio-optical classification and model of natural waters, Limnol. Oceanogr., 27, 500-509, 1982.

Balch, W. M., R. W. Eppley, M. R. Abbott, and M. H. Reid, Bias in satellite-derived pigment measurements due to coccolithophores and dinoflagellates, J. Plankton Res., 11, 575-581, 1989.

Betzer, P. R., D. W. Eggiman, K. L. Carder, D. R. Kester, and S. B. Betzer, Seasonal patterns in suspended calcium carbonate concentration during the dry and wet seasons in the eastern Caribbean, in The Fate of Fossil Fuel $\mathrm{CO}_{2}$ in the Oceans, edited by N. R. Andersen and A. Malahoff, pp. 63-79, Plenum, New York, 1977.

Bidigare, R. R., M. E. Ondrusek, and J. M. Brooks, Influence of the Orinoco River outflow on distributions of algal pigments in the Caribbean Sea, J. Geophys. Res., 98(C2), 2259-2269, 1993.

Blough, N. V., O. C. Zafiriou, and J. Bonilla, Optical absorption spectra of waters from the Orinoco River outflow: Terrestrial input of colored organic matter to the Caribbean, J. Geophys. Res., 98(C2), 2271-2278, 1993.

Bricaud, A., A. Morel, and L. Prieur, Absorption by dissolved organic matter of the sea (yellow substance) in the UV and visible domains, Limnol. Oceanogr., 26, 43-53, 1981.

Brown, J. W., Studies of humic and fulvic acid dynamics in coastal marine waters of South Florida, Mar. Environ. Res., 21, 163-174, 1987.

Carder, K. L., R. G. Steward, G. R. Harvey, and P. B. Ortner, Marine humic and fulvic acids: Their effects on remote sensing of ocean chlorophyll, Limnol. Oceanogr., 34, 61-68, 1989.

Gordon, H. R., and D. K. Clark, Clear water radiances for atmospheric correction of coastal zone color scanner imagery, Appl. Opt., 20, 4175-4180, 1981 .

Gordon, H. R., and A. Morel, Remote Assessment of Ocean Color for Interpretation of Satellite Visible Imagery: A Review, 114 pp., Springer-Verlag, New York, 1983.

Gordon, H. R., D. K. Clark, J. W. Brown, O. B. Brown, R. H. Evans, and W. W. Brinks, Phytoplankton pigment concentrations in the Middle Atlantic Bight: Comparison of ship determinations and CZCS estimates, Appl. Opt., 22, 20-35, 1983.

Gordon, H. R., O. B. Brown, R. H. Evans, J. W. Brown, R. C. Smith, K. S. Baker, and D. K. Clark, A semianalytic radiance model of ocean color, J. Geophys. Res., 93(D9), 10,909-10,924, 1988.

Harvey, G. R., D. A. Boran, L. A. Chesal, and J. M. Tokar, The structure of marine fulvic and humic acids, Mar. Chem., 12 , 119-132, 1983.

Morel, A., Optical properties of pure water and pure sea water, in Optical Aspects of Oceanography, edited by N. G. Jerlov and E. S. Nielson, pp. 1-24, Academic, San Diego, Calif., 1974.

Morel, A., and L. Prieur, Analysis of variations in ocean color, Limnol. Oceanogr., 22, 709-722, 1977.

Müller-Karger, F. E., C. R. McClain, and P. L. Richardson, The dispersal of the Amazon's water, Nature, 333, 56-59, 1988.

Müller-Karger, F. E., C. R. McClain, T. R. Fisher, W. E. Esaias, and $\mathbf{R}$. Varela, Pigment distribution in the Caribbean Sea: Observations from space, Prog. Oceanogr., 23, 23-64, 1989.

Platt, T., C. Caverhill, and S. Sathyendranath, Basin-scale estimates of oceanic primary production by remote sensing: The North Atlantic, J. Geophys. Res., 96(C8), 15,147-15,159, 1991.

Smith, R. C., and K. S. Baker, Optical classification for natural waters, Limnol. Oceanogr., 23, 260-267, 1978a.

Smith, R. C., and K. S. Baker, The bio-optical state of ocean waters and remote sensing, Limnol. Oceanogr., 23, 247-259, 1978b.

Ulloa, O., S. Sathyendranath, T. Platt, and R. A. Quinones, Light scattering by marine heterotrophic bacteria, J. Geophys. Res., 97(C6), 9619-9629, 1992.

Walsh, J. J., G. T. Rowe, R. L. Iverson, and C. P. McRoy, Biological export of shelf carbon is a neglected sink of the global $\mathrm{CO}_{2}$ cycle, Nature, 291, 196-201, 1981.

Walsh, J. J., K. L. Carder, and F. E. Müller-Karger, Meridional fluxes of dissolved organic matter in the North Atlantic Ocean, $J$. Geophys. Res., 97(C10), 15,625-15,638, 1992.

Yoshioka, P. M., G. P. Owen, and D. Pesante, Spatial and temporal variations in Caribbean zooplankton near Puerto Rico, J. Plankton Res., 7, 733-751, 1985.

H. T. Hochman, F. E. Müller-Karger, and J. J. Walsh, Department of Marine Science, University of South Florida, 140 Seventh Avenue South, St. Petersburg, FL 33701.

(Received January 6, 1993; revised March 30, 1993; accepted August 4, 1993.) 